\title{
Competitive analysis of soybean and sudangrass using replacement series design
}

\author{
Mauro Antônio Rizzardi ${ }^{1 *}$, Alana Cristina Dorneles Wandscheer ${ }^{2}$, Andrea Ferreira Hoffmann ${ }^{2}$
}

$10.1590 / 0034-737 X 201663050011$

\begin{abstract}
Competition is the best known form of direct interference of weeds on agricultural crops. However, there is relatively little information on the competition of the weed sudangrass on soybean, which has been common in agricultural areas in the southern of Rio Grande do Sul. The objective of this study was to evaluate the competition between sudangrass and soybeans using replacement series experiments. The experiment was carried out in a greenhouse in a completely randomized design with four replications. The treatments consisted of soybean and sudangrass associations. The experimental units were 8-L plastic pots, in the proportions $0: 8,2: 6,4: 4,6: 2,8: 0$, corresponding to $0,25,50,75$ and $100 \%$ of the crop and weed respectively. Shoot, root and total dry matter and plant height were analyzed through diagrams applied to replacement series and competitive indices. Soybean showed competitive superiority in coexistence with sudangrass in relation to shoot, root and total dry matter. The intraspecific competition was more significant for the crop and inter-specific competition was more important for the weed.
\end{abstract}

Keywords: Sorghum sudanense (Piper) Stapf; Glycine max (L.) Merr; competition; weed.

\section{RESUMO}

\section{Análise competitiva entre plantas de soja e capim-sudão por meio de experimento substitutivo}

A competição é a forma mais conhecida de interferência direta das plantas daninhas em culturas agrícolas. Entretanto, há relativamente pouca informação sobre a competitividade da espécie daninha capim-sudão sobre a cultura da soja, cuja presença tem sido frequente em áreas agrícolas do sul do estado do Rio Grande do Sul. Objetivou-se nessa pesquisa verificar a competição entre plantas de soja e capim-sudão, por meio de experimentos em série de substituição. $\mathrm{O}$ experimento foi realizado em casa-de-vegetação, em delineamento inteiramente casualizado e quatro repetições. Os tratamentos constaram de associações de plantas de soja e capim-sudão, cujas unidades experimentais foram vasos plásticos de $8 \mathrm{~L}$, nas proporções de 0:8, 2:6, 4:4, 6:2, 8:0, respectivamente, que corresponderam a 0, 25, 50, 75 e $100 \%$ da cultura e da planta daninha. Matéria seca da parte aérea, raiz e total e estatura de plantas foram analisadas por meio de diagramas aplicados a experimentos substitutivos e índices de competitividade. Plantas de soja apresentaram superioridade competitiva quando em convivência com plantas de capim-sudão, para matéria seca da parte aérea, raiz e total. A competição intra-específica foi mais significativa para a cultura e a competição inter-específica foi mais importante para a planta daninha.

Palavras-chave: Sorghum sudanense (Piper) Stapf; Glycine max (L.) Merr; competição; planta daninha.

\footnotetext{
Submitted on March 07 2014 and accepted on August $04^{\text {th }}, 2016$

${ }^{1}$ Universidade de Passo Fundo, Passo Fundo, Rio Grande do Sul, Brazil. Bolsista CNPq. mar.rizzardi@gmail.com

Universidade de Passo Fundo, Programa de Pós-graduação em Agronomia, Passo Fundo, Rio Grande do Sul, Brazil. alanacdw@gmail.com; af.hoffmann@gmail.com *Corresponding author: mar.rizzardi@gmail.com
} 


\section{INTRODUCTION}

Competition begins from the moment that the availability of a particular resource is below that required by plants. This process accounts for yield decline in commercial species as well as loss of desired populations and weed invasion, but also can lead to increases in yield and stability of crops (Dias-Filho, 2006). Moreover, the competitive ability of a species is closely related to its capacity of using the environmental resources (Rizzardi et al., 2001). For Berger et al. (2008), competition is a key process in communities or populations of plants and in order to predict the responses of ecological systems, a comprehensive and mechanistic understanding of the competition between plants is required.

Competitive interactions may be influenced by factors such as size, age and genotype of the plant. Furthermore, physiological and physical space colonization strategies may be important in the competitive process (Bittebiere et al., 2012). The replacement series method stands out among the existing models to evaluate the competition between species (Fleck et al., 2008). It includes analyses of the species under investigation both in monocultures and mixed stands, wherein the proportions of the two species vary while the final density is maintained constant for all treatments (Cousens, 1991; Radosevich et al., 1997).

In farm lands, the crop population is kept constant while the weed population varies according to the degree of site infestation. Thus, determining the variation in the ratio between populations of crop plants and weed species is important for competition studies, as it allows one to measure the influence of the population on the competitive process and the influence of the variation on the proportion between species (Christoffoleti \& Victoria Fiho, 1996; Moraes et al, 2009).

Sudangrass (Sorghum sudanense (Piper) Stapf) has been found in farm lands in the southern of Rio Grande do Sul. It is an annual plant propagated by seeds and having no rhizomes, which makes it different from Sorghum halepense. However, it has a well-developed crown and fasciculate roots, very similar to Sorghum arundinaceum, but differs from it by having persistent pedicellate spikelets, which by rachis breaking up. In normal conditions and large space to grow, the plant can develop up to one hundred stems from the crown (Kissmann, 1997).

The hypothesis of this research is that soybean plants have superior competitive ability to sudangrass when both species are found in equal proportions in the same conditions and resources. Whereas sudangrass can interfere with soybean yield trough a competitive process in farm lands and, because of the lack of information on the competitiveness of this species, the aim of this study was to evaluate the competition between soybean and sudangrass weed using replacement series experiments.

\section{MATERIAL AND METHODS}

The experiment was carried out in a greenhouse, in 2011/12. The experimental units consisted of plastic pots (8 L capacity; $25 \mathrm{~cm}$ depth) filled with soil derived from the experimental area, which is classified as Dystrophic Red Latosol. The treatments were arranged in a completely randomized design with four replications.

Initially, soybean was sown into the experimental units and weed was sown one day after, so that the two species emerged at the same time to obtain seedlings with the same developmental stage. For this purpose, a preliminary experiment was carried out to evaluate the period required from germination to emergence of the two species, which was seven days for soybean and six days for sudangrass.

The treatments were combinations of soybean and weed plants in the proportions 8:0, 6:2, 4:4, 2:6, 0:8, i.e., 100, $75,50,25$ and $0 \%$ soybean (Glycine $\max$ (L.) Merr cultivar NA 5909 RG) and the opposite for sudangrass. The plat density used for each experimental unit was obtained accordance to the "Law of Final Constant Yield" determined in other assays, in which the population was eight plants per pot, totaling 250 plants $\mathrm{m}^{-2}$.

At 60 days after soybean emergence, plants of the experimental units were collected to evaluate height and shoot, root and total dry matter. Plant height $(\mathrm{cm})$ was measured from the base to the end of the last leaf. For dry matter $(\mathrm{g})$, shoots and roots dried in an oven at $60^{\circ} \mathrm{C}$ for 72 hours and weighed on an analytical balance. Total dry matter corresponds to the sum of shoot and root dry matter in each proportion.

Variables were subjected to graphical or conventional analysis for replacement experiments, which consists of the construction of diagrams based on the relative yield (RY) (Roush et al., 1989; Cousens, 1991) through the construction diagrams based on the relative productivity (RP) in the proportions $0,25,50,75$ and $100 \%$ of crop and weed.

The relative yield of the variables was calculated by dividing the mixture average by the monoculture average, including in the calculation the average per plant of each species in each experimental unit. The TRY represents the sum of the relative yields of the competitors in the respective plant proportions.

The equations for calculating the relative yields and total yields according to Hoffman \& Buhler (2002) are as follows: RYa = (p) $($ Amix / Amon); RYb = (1 - p) $($ Bmix / bmon); TRY = RYa + RYb, where RYa = relative yield of the species " $\mathrm{a}$ " (crop); $\mathrm{RYb}=$ relative yield of the species "B" (weed); $p=$ proportion of " $a$ " in \% divided by 100; Amix = value of the variable to be analyzed (for example: dry matter) of "A" in mixture; Amon = value of the variable to be analyzed of " $A$ " in monoculture; $B$ mix = value of the 
variable to be analyzed of " $\mathrm{B}$ " in mixture; $\mathrm{Bmon}=$ value of the variable to be analyzed of " $\mathrm{B}$ " in monoculture; TRY = Total relative yield.

The indices of relative competitiveness (RC), relative clustering coefficients (K) and aggressiveness (A) were calculated in the proportion of $50 \%$ soybean and sudangrass. RC is the comparative growth of the species A (soybean) in relation to species B (sudangrass); K indicates the relative dominance of one species over another; and A points out which species is more competitive. The joint interpretation of these values allows us to infer the degree of competition between species with greater security (Cousens, 1991). Species A is more competitive than the species $\mathrm{B}$ when $\mathrm{RC}>1, \mathrm{Ka}>\mathrm{Kb}$ and $\mathrm{A}>0$. Species B is more competitive when is $\mathrm{RC}<1, \mathrm{Ka}<$
$\mathrm{Kb}$ and $\mathrm{A}<0$. The equations for calculating these indices according to Hoffman \& Buhler (2002) are as follows: RC = $((1-p) / p)(R Y a / R Y b) ; K a=((1-p) / p)(R Y a /(1-R Y a)) ; K b$ $=((1-p) / p)(R Y b /(1-R Y b)) ; A=(R Y a / 2 p)-(R Y b /(2(1$ $-\mathrm{p}))$ ).

For statistical analysis of the relative yield, differences for RY values (RYD) obtained in the proportions 25, 50 and $75 \%$ of plants were primarily calculated in relation to the values belonging to the hypothetical lines in the following proportions: $0.25,0.50$ and 0.75 . The $\mathrm{T}$ test at $5 \%$ of probability level was used to test the differences relative to RYD, TRY, RC, $\mathrm{K}$ and $\mathrm{A}$ indices in relation to the hypothetical lines (Hoffman \& Buhler, 2002), with the statistical software SAS (Statistical Analysis System version 8.0).
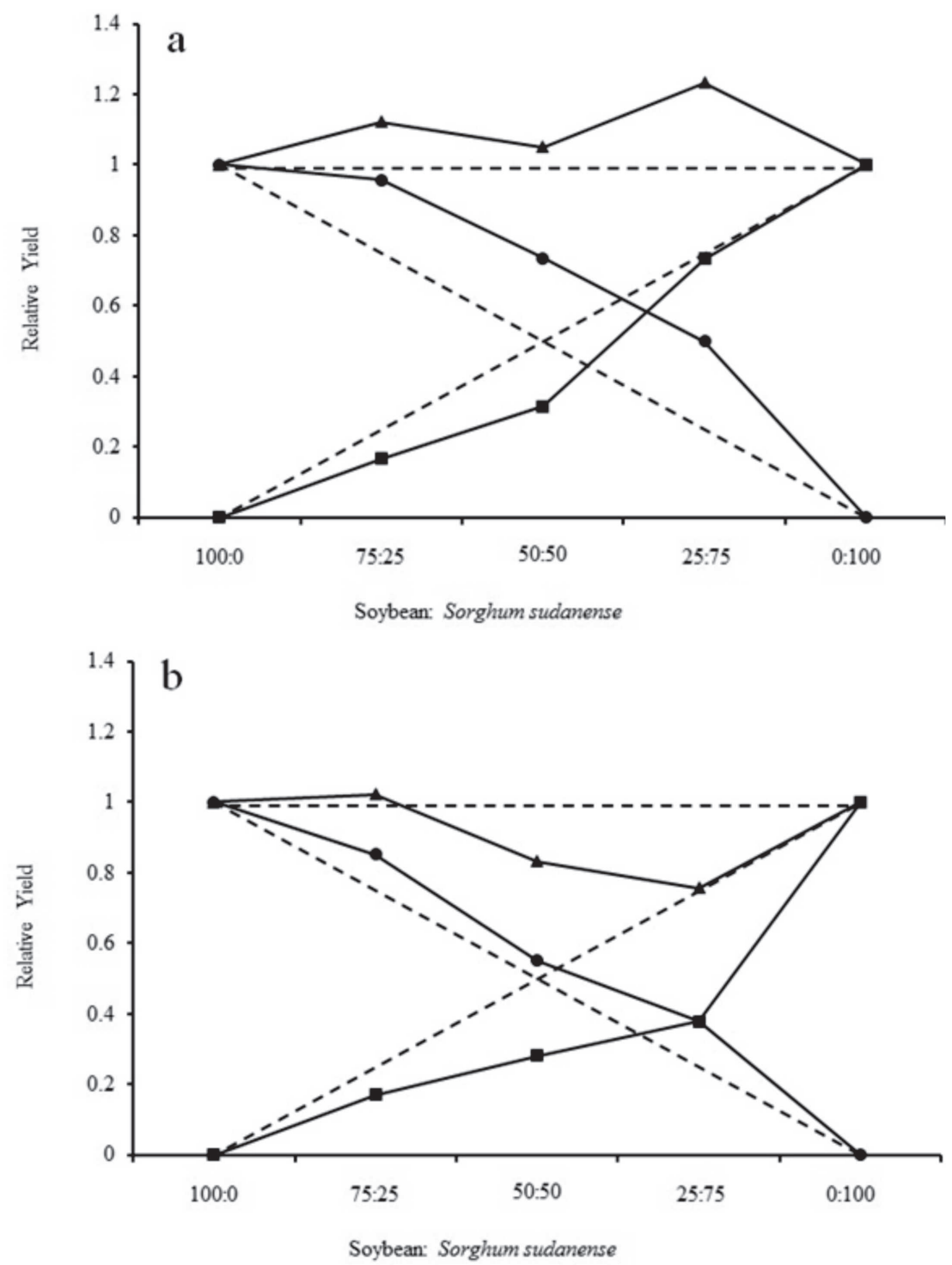

$(\bullet)$ RY of soybean cultivar $(\boldsymbol{\bullet})$ RY of competitor and ( $\mathbf{\Delta})$ TRY. Dashed lines represent the hypothetical relative yields when there is no interference of one species over another.

Figure 1: Relative Yield (RY) and total relative yield (TRY) for shoot dry matter (a) and root dry matter (b) of soybean and Sorghum sudanense, as a function of the plant proportion. 
The null hypotheses to test the differences of RYD and $\mathrm{A}$ stated that the averages were equal to zero $(\mathrm{H} 0=0)$; that averages were equal to one $(\mathrm{H} 0=1)$ for RYT and RC; and that the mean differences between $\mathrm{Ka}$ and $\mathrm{Kb}$ were equal to zero $[\mathrm{HO}=(\mathrm{Ka}-\mathrm{Kb})=0]$ for the index $\mathrm{K}$.

Data on shoot dry matter, root dry matter, total dry matter and plant height, which were expressed as mean values per plant, were subjected to analysis of variance and the means were compared by the Dunnett test ( $\mathrm{p} \mathrm{d}$ " 0.05 ), considering the monocultures as controls, with the statistical software ASSISTAT version 7.6 beta - 2011 .

\section{RESULTS AND DISCUSSION}

The results showed that soybean produced more shoot dry matter than expected in all combinations with weed, and the relative yield was significantly higher when in the higher density of sudangrass (proportion 25/75). This indicates that the competitor probably does not recruit all soil resources and makes them available to soybean which, in turn, develops normally even in lower densities. For the competitor, the association with soybeans was especially harmful when the crop was in equal and higher proportions (50/50 and 75/25). The TRY of shoot dry matter indicated that there was no species competition in the proportion in which the weed was in higher density, since in this proportion, the amount of resources was probably sufficient for the survival of the two species (Figure 1a and Table 1).
In competition assays between soybean and turnip, it was found that the turnip has higher competitive ability, in which RY lines of soybean were concave and RY lines of turnip were convex (Bianchi et al., 2006), contrarily to what can be seen in this study.

Rizzardi et al. (2004) found that in the association between soybean and the weed species common morning glory (Ipomoea grandifolia) and wild poinsettia (Euphorbia heterophylla) there is a mutual benefit between the species, both producing more than the expected in all plant proportions, which can be related to the fact that the amount of resources available for the species was sufficient to avoid competition. However, when in mixed communities, common morning glory is more competitive than wild poinsettia.

There were no losses of root dry matter by competitive effects for soybean, and the production increased when the weed was in higher density, which shows that for soybean intraspecific competition is more important. However, the weed reduced root dry matter production when used in combination with the crop in all proportions (Figure 1b). The less competitive ability of sudangrass relative to root may be due to the lack of rhizomes, differing from other Sorghum species such as Sorghum halepense (Kissmann, 1997).

TRY for root dry matter indicated that there was competition between the two species, especially in the proportions 50/50 and 25/75 (soybean:competitor), but differed significantly from the expected result only in the

Table 1: Relative Yield Differences (RYD) for the variables shoot dry matter, root dry matter, total dry matter and plant height; and total relative yield (TRY), in the proportions $75 / 25,50 / 50$ and 25/75 of soybean associated with sudangrass

\begin{tabular}{|c|c|c|c|}
\hline \multicolumn{4}{|c|}{ Plant proportion (soybean /sudangrass) } \\
\hline & $75 / 25$ & $50 / 50$ & $25 / 75$ \\
\hline \multicolumn{4}{|l|}{ SDM $^{1}$} \\
\hline RYD soybean & $0.21( \pm 0.15)^{\mathrm{ns}}$ & $0.24( \pm 0.12)^{\mathrm{ns}}$ & $0.25( \pm 0.08) *$ \\
\hline RYD sudangrass & $-0.08( \pm 0.01) *$ & $-0.19( \pm 0.02) *$ & $-0.02( \pm 0.03)^{\mathrm{ns}}$ \\
\hline TRY & $1.12( \pm 0.16)^{\mathrm{ns}}$ & $1.05( \pm 0.12)^{\mathrm{ns}}$ & $1.23( \pm 0.06) *$ \\
\hline \multicolumn{4}{|l|}{$\mathbf{R D M}^{2}$} \\
\hline RYD soybean & $0.10( \pm 0.13)^{\mathrm{ns}}$ & $0.05( \pm 0.07)^{\mathrm{ns}}$ & $0.13( \pm 0.01) *$ \\
\hline RYD sudangrass & $-0.08( \pm 0.02)^{*}$ & $-0.22( \pm 0.01) *$ & $-0.37( \pm 0.08)^{*}$ \\
\hline TRY & $1.02( \pm 0.14)^{\mathrm{ns}}$ & $0.83( \pm 0.07)^{\mathrm{ns}}$ & $0.76( \pm 0.07) *$ \\
\hline \multicolumn{4}{|l|}{ TDM $^{3}$} \\
\hline RYD soybean & $0.19( \pm 0.13)^{\mathrm{ns}}$ & $0.20( \pm 0.11)^{\mathrm{ns}}$ & $0.23( \pm 0.06) *$ \\
\hline RYD sudangrass & $-0.09( \pm 0.01) *$ & $-0.21( \pm 0.01)^{*}$ & $-0.16( \pm 0.04) *$ \\
\hline TRY & $1.10( \pm 0.14)^{\mathrm{ns}}$ & $0.99( \pm 0.10)^{\mathrm{ns}}$ & $1.06( \pm 0.05)^{\mathrm{ns}}$ \\
\hline \multicolumn{4}{|l|}{$\mathbf{P H}^{4}$} \\
\hline RYD soybean & $-0.01( \pm 0.02)^{\mathrm{ns}}$ & $0.002( \pm 0.03)^{\mathrm{ns}}$ & $0.02( \pm 0.01)^{\mathrm{ns}}$ \\
\hline RYD sudangrass & $0.01( \pm 0.03)^{\mathrm{ns}}$ & $-0.002( \pm 0.04)^{\mathrm{ns}}$ & $0.04( \pm 0.06)^{\mathrm{ns}}$ \\
\hline TRY & $1.00( \pm 0.04)^{\mathrm{ns}}$ & $1.00( \pm 0.07)^{\mathrm{ns}}$ & $1.06( \pm 0.07)^{\mathrm{ns}}$ \\
\hline
\end{tabular}


proportion in which the competitor was in higher density (25/75). In this proportion there was competition between species, but only the weed had its yield hampered (Figure $1 \mathrm{~b}$ and Table 1).

Zanine \& Santos (2004) emphasize that the occupation of the soil space by the roots is crucial in competition, and that between plants of different species there may also be differences in relation to the root system.

It should be noted that the TRY of root dry matter was negative while the TRY of shoot dry matter showed positive values (Figure 1), indicating that the competition affected more significantly root production than shoot of the weed.

The total dry matter for both species reflects the yield of shoot and root dry matter. Thus, it showed similar behavior to these variables, in which soybean was not affected by the association with the weed in all proportions and even showed an increase in the relative production of total dry matter when the weed was in higher density (25/ 75). On the other hand, the weed was hampered by the association in all combinations with soybean. The TRY of total dry matter did not differ significantly from the expected values, indicating that the competition occurred for the same environmental resource (Figure $2 \mathrm{a}$ and Table 1).

The competitive success of soybean with weeds is primarily attributed to its growth characteristics such as height and shoot dry matter accumulation (Agostinetto et al., 2009). Moraes et al. (2009) found that soybean was more competitive than red rice. Similarly, soybean showed
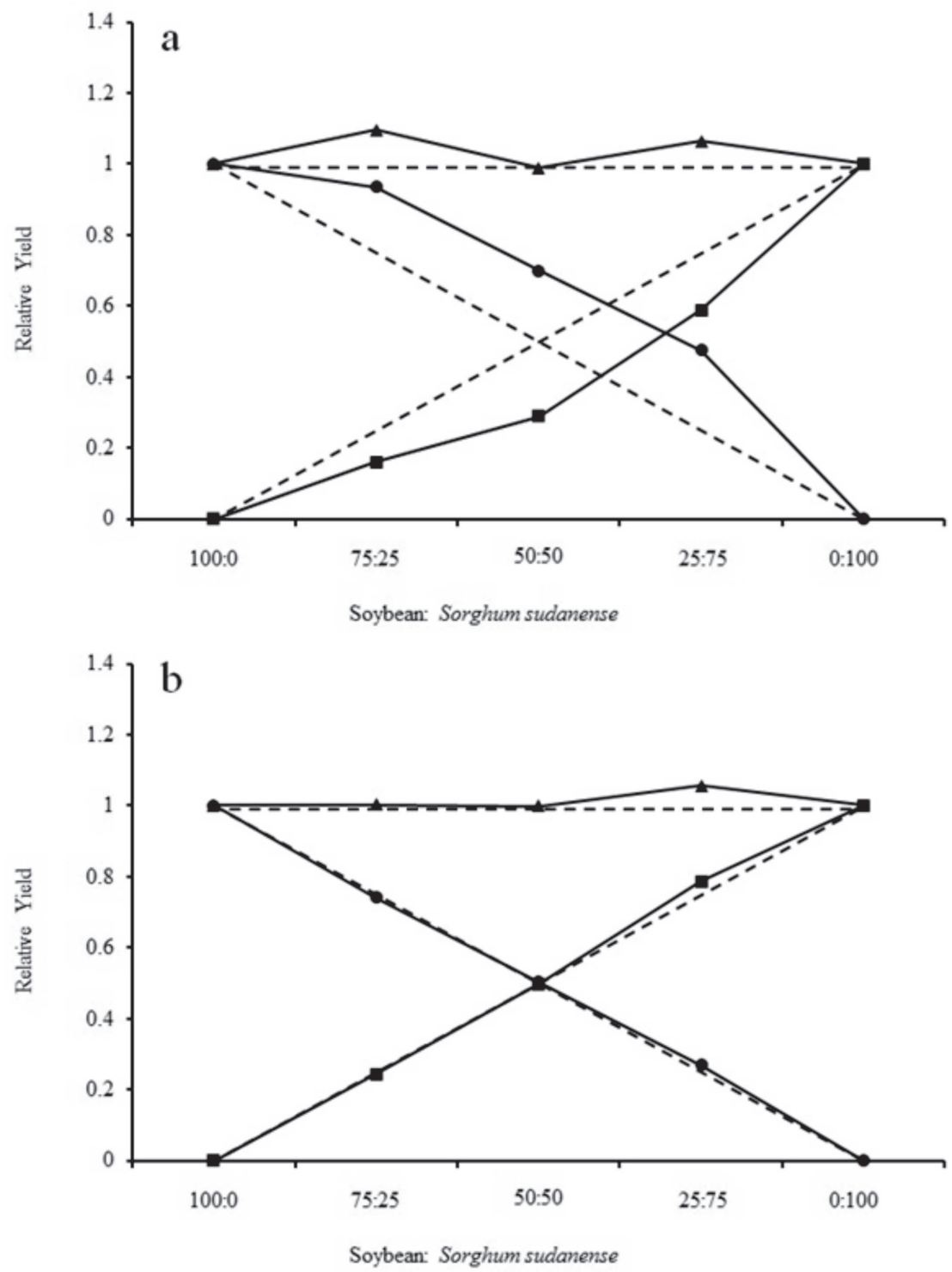

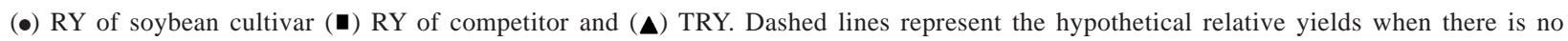
interference of one species over another.

Figure 2: Relative Yield (YR) and Total Relative Yield (TRY) for total dry matter (root + shoot) (a) and height (b) of soybean and Sorghum sudanense, as a function of the plant proportion. 
greater competitive ability in coexistence with Jamaican crabgrass (Digitaria horizontalis Willd. (DIGHO)), and both species compete for the same environmental resources (Fontana et al., 2010).

Both species showed similar behavior for plant height. The results did not differ significantly from the expected values in all species proportions, indicating that the height of the two species is not affected by the association and the plants can grow in stature as if in pure stands. The TRY shows that there is competition for the same environmental resources, with the production line obtained being similar to the expected line (Radosevich et al., 1997) (Figure $2 \mathrm{~b}$ and Table 1).

Table 2 shows the indices of relative competitiveness (RC), relative clustering coefficients (K) and aggressiveness (A) of the two species when in equal proportions. Taking into account that soybean is more competitive than sudangrass when $\mathrm{RC}>1, \mathrm{Ks}>\mathrm{Kc}$ and A $>0$ (Hoffman \& Buhler, 2002), it was found that A was above zero for the variables shoot, root and total dry matter, which indicates that soybean is more aggressive than sudangrass. In addition, the RC index, which compares the relative growth between the two species, shows that soybean is more competitive and grow faster than the weed when they emerge together, which agrees with the report by Hoffman \& Buhler (2002), who found that the crop had greater competitiveness than the weed when analyzing cultivated sorghum and Sorghum halepense.

Table 3 also showed that for soybean, the intraspecific competition is more significant than the inter-specific competition, as it produced more when close to a sudangrass plant than a plant of its own species. On the other hand, for sudangrass, the inter-specific competition is more important and it prefers a plant of its own species than a soybean plant. Table 4 shows the mean square error for the characteristics shoot dry matter, root dry matter, total dry matter and height of soybean plants and Sorghum sudanense.

The ability of a plant to compete with another depends on factors such as species, population, emergence time and morphophysiological characteristics. For soybeans in competition with Alexander grass (Urochloa plantaginea), there was antagonism in the growth of both species and intra-specific competition was higher than the inter-specific competition (Agostinetto et al., 2009).

At the lowest proportion of soybean, there was gain of shoot dry matter in relation to monocultures. The same was true for root and total dry matter. Moraes et al. (2009) found the same behavior in soybean competing with red rice. The authors pointed out that this may happen because

Table 2: Competitiveness indices of soybean and sudangrass expressed by relative competitiveness (RC), clustering coefficients (K) and aggression (A)

\begin{tabular}{lcccc}
\hline Variables & $\mathbf{R C}$ & $\mathbf{K}_{\mathrm{s}=\text { soybean }}$ & $\mathbf{K}_{\mathbf{c}=\text { sudangrass }}$ & $\mathbf{A}^{\mathrm{n}}$ \\
\hline${ }^{1} \mathrm{SDM}$ & $2.39( \pm 0.45)^{\mathrm{ns}}$ & $9.37( \pm 5.73)^{\mathrm{ns}}$ & $0.46( \pm 0.04)^{\mathrm{ns}}$ & $0.42( \pm 0.12)^{*}$ \\
${ }^{2} \mathrm{RDM}$ & $2.00( \pm 0.33)^{\mathrm{ns}}$ & $1.51( \pm 0.58)^{\mathrm{ns}}$ & $0.39( \pm 0.02)^{\mathrm{ns}}$ & $0.27( \pm 0.08)^{*}$ \\
${ }^{3} \mathrm{TDM}$ & $2.45( \pm 0.41)^{*}$ & $4.8( \pm 2.59)^{\mathrm{ns}}$ & $0.40( \pm 0.02)^{\mathrm{ns}}$ & $0.41( \pm 0.11)^{*}$ \\
${ }^{4} \mathrm{PH}$ & $1.02( \pm 0.07)^{\mathrm{ns}}$ & $1.03( \pm 0.12)^{\mathrm{ns}}$ & $1.03( \pm 0.17)^{\mathrm{ns}}$ & $0.01( \pm 0.03)^{\mathrm{ns}}$ \\
\hline
\end{tabular}

${ }^{\mathrm{n}}$ Non-significant and $*$ significant by the $\mathrm{t}$ test (p d" 0.05 ). ${ }^{1} \mathrm{SDM}$ : shoot dry matter; ${ }^{2} \mathrm{RDM}$ : root dry matter; ${ }^{3} \mathrm{TDM}$ : total dry matter (root + shoot); ${ }^{4} \mathrm{PH}$ : plant height.

Table 3: Soybean response to interference with sudangrass, 60 days after emergence

\begin{tabular}{|c|c|c|c|c|c|c|}
\hline \multicolumn{7}{|c|}{ Plant proportions (soybean/sudangrass) } \\
\hline \multicolumn{7}{|l|}{${ }^{1} \mathrm{SDM}$} \\
\hline Soybean & 4.23 & 5.40 & 6.22 & $8.47 *$ & - & 30.33 \\
\hline Sudangrass & - & $0.75^{*}$ & $0.71 *$ & 1.10 & 1.21 & 12.63 \\
\hline \multicolumn{7}{|l|}{${ }^{2} \mathrm{RDM}$} \\
\hline Soybean & 1.03 & 1.17 & 1.14 & $1.56^{*}$ & - & 20.60 \\
\hline Sudangrass & - & $0.38^{*}$ & $0.32 *$ & $0.28 *$ & 0.56 & 22.73 \\
\hline \multicolumn{7}{|l|}{${ }^{3} \mathrm{TDM}$} \\
\hline Soybean & 5.27 & 6.57 & 7.37 & $10.03^{*}$ & - & 27.09 \\
\hline Sudangrass & - & $1.14 *$ & $1.03 *$ & $1.40^{*}$ & 1.78 & 13.04 \\
\hline \multicolumn{7}{|l|}{${ }^{4} \mathrm{PH}$} \\
\hline Soybean & 45.63 & 45.11 & 45.87 & 49.31 & - & 7.45 \\
\hline Sudangrass & - & 63.18 & 60.03 & 63.29 & 60.38 & 17.11 \\
\hline
\end{tabular}


Table 4: Mean square error of the variables shoot dry matter (SDM), root dry matter (RDM), total dry matter (TDM) and height (HEI) of soybean and Sorghum sudanense

\begin{tabular}{lrccrr}
\hline & \multicolumn{5}{c}{ Variables } \\
\cline { 2 - 6 } FV & DF & \multicolumn{4}{c}{ Soybean } \\
\cline { 2 - 6 } & & SDM & RDM & TDM & STAT \\
\hline Treatments (combinations) & 3 & 12.83217 & 0.21291 & 1.09692 & 292.95962 \\
Error & 12 & 3.40129 & 0.06366 & 0.09397 & 0.91037 \\
\hline & & & Sorghum sudanense & STAT \\
\cline { 2 - 6 } & & SDM & RDM & TDM & 460.22303 \\
Treatments (combinations) & 3 & 0.25266 & 0.06286 & 0.08341 & 15.01688 \\
Error & 12 & 0.01399 & 0.00786 & 0.01244 & \\
\hline FV: & & & & & \\
\end{tabular}

FV: factor of variation; DF: degrees of freedom

of the soybean capacity to branch when in the presence of the weed, in comparison with the presence of its own species.

In general, replacement experiments show that the crop is more competitive than the weed because the effect that weeds have on crops is due to their density in the crop, and not to the individual competitive capacity (Roush et al., 1989; Bianchi et al., 2006).

The results obtained from the experiments of soybean competition with sudangrass show that the crop was more competitive than the weed, and in general the line of soybean yields is convex and that of sudangrass is concave (Figures 1 and 2). This result shows that one species was more aggressive than the other and contributed more than the expected for total yield (Radosevich et al., 1997). It also means that there was an interaction of the species for the same resources, but the soybean used them more efficiently (Moraes et al., 2009).

The competition between the species tends to be greater the more similar the environmental requirements are and the more similar the growing habit of the species involved is (Vargas et al., 2006). In this context, it is observrd that the structure and the yield of the plant communities can be profoundly influenced by the competitive relationships that occur in the environment, and the result of this process depends on the initial growth rate of each species involved (Nisensohn et al., 2011).

\section{CONCLUSIONS}

Soybean has competitive advantage in relation to sudangrass, which was observed in the dry matter variables. The intraspecific competition is more important than interspecific competition for the soybean crop, whereas the opposite was observed for the weed sudangrass.

\section{ACKNOWLEDGEMENTS}

The authors thank to CNPq and CAPES for the financial support and research grants.

\section{REFERENCES}

Agostinetto D, Rigoli RP, Galon L, Moraes PVD de \& Fontana LC (2009) Competitividade relativa da soja em convivência com papuã (Brachiaria plantaginea). Scientia Agraria, 10:185-190.

Berger U, Piou C, Schiffers K \& Grimm V (2008) Competition among plants: concepts, individual-based modeling approaches, and a proposal for a future research strategy. Perspectives in Plant Ecology, Evolution and Systematics, 9:121-135.

Bianchi MA, Fleck NG \& Lamego FP (2006) Proporção entre plantas de soja e plantas competidoras e as relações de interferência mútua. Ciência Rural, 36:1380-1387.

Bittebiere AK, Mony C, Clément B \& Garbey M (2012) Modeling competition between plants using an individual based model: methods and effects on the growth of two species with contrasted growth forms. Ecological Modelling, 234:38-50.

Christoffoleti PJ \& Victoria Filho R (1996) Efeitos da densidade e proporção de plantas de milho (Zea mays L.) e caruru (Amaranthus retroflexus L.) em competição. Planta Daninha, 14:42-47.

Cousens R (1991) Aspects of the design and interpretation of competition (interference) experiments. Weed Technology, 5:664-673.

Dias-Filho MB (2006) Competição e sucessão vegetal em pastagens. Belém, Embrapa Amazônia Oriental. 38p. (Documentos Online, 240).

Fleck NG, Agostinetto D, Galon L \& Schaedler CE (2008) Competitividade relativa entre cultivares de arroz irrigado e biótipo de arroz-vermelho. Planta Daninha, 26:101-111.

Fontana LC, Markus C, Polidoro E, Oliveira C de, Westendorff N da R \& Agostinetto D (2010) Interferência entre soja (Glycine max) e milhã (Digitaria ciliaris). In: Congresso de Iniciação Científica, Pelotas. Anais, UFPel. p. 778-781.

Hoffman ML \& Buhler DD (2002) Utilizing Sorghum as a functional model of crop-weed competition. I. Establishing a competitive hierarchy. Weed Science, 50:466-472.

Kissmann KG (1997) Plantas infestantes e nocivas. $2^{\text {a }}$ ed. São Paulo, BASF Brasileira S.A.825p.

Moraes PVD, Agostinetto D, Galon L \& Rigoli LP (2009) Competitividade relativa de soja com arroz-vermelho. Planta Daninha, 27:35-40.

Nisensohn L, Tuesca D, Faccini D, Puricelli E \& Vitta J (2011) Factores biológicos que determinan la competencia de Commelina erecta con otras malezas em sistemas de cultivo. Planta Daninha, 29:97-106. 
Radosevich SR, Holt JS \& Ghersa CM (1997) Plant-plant associations. In: Radosevich SR, Holt JS, Ghersa CM (Eds.) Ecology of weeds and invasive plants: relationship to agriculture and natural resource management. $3^{\mathrm{a}}$ ed. New Jersey, John Wiley \& Sons. $454 \mathrm{p}$.

Rizzardi MA, Fleck NG, Vidal RA, Merotto Jr A \& Agostinetto D (2001) Competição por recursos do solo entre ervas daninhas e culturas. Ciência Rural, 31:707-714.

Rizzardi MA, Roman ES, Borowski DZ \& Marcon R (2004) Interferência de populações de Euphorbia heterophylla e Ipomoea ramosissima isoladas ou em misturas sobre a cultura de soja. Planta Daninha, 22:29-34.
Roush ML, Radosevich SR, Wagner RG, Maxwell BD \& Petersen TD (1989) A comparison of methods for measuring effects of density and proportion in plant competition experiments. Weed Science, 37:268-275.

Vargas L, Peixoto CM \& Roman ES (2006) Manejo de plantas daninhas na cultura do milho. Passo Fundo, Embrapa Trigo. 20p. (Documentos Online, 61).

Zanine A de M \& Santos EM (2004) Competição entre espécies de plantas - uma revisão. Revista da FZVA, 11:10-30. 